\title{
GROWTH OF IMMIGRANT POPULATION AND HOMEGROWN TERRORISM IN EUROPE
}

\author{
Naser Etemi, PhD \\ First Private University FON Skopje, Faculty for Detectives and Security \\ E-mail: naser.etemi@fon.edu.mk \\ Amir Dalipi \\ Governement of Republic of Macedonia, Ministry of Interior \\ E-mail: amir dalipi 78@hotmail.com \\ Sevil Muaremoska, PhD student \\ First Private University FON Skopje, Faculty for Detective and Security \\ E-mail: sevil.muaremoska@fon.edu.mk
}

\begin{abstract}
It is clear from the past, that mass migration seeking paradise, new opportunities facilitate distribution of terrorism. The fact that at least one of the terrorists of 13 November in Paris entered the European Union via the Balkan route, Berlin atacker indicates that the phenomenon of sleepy Islamists should not be underestimated in the context of migration. Fears of an alleged strategy of the Trojan Horse of the Islamic State, a strategy that has intensified in January 2015. According to the self-acknowledged smuggler who operates in Turkey, claims to have been sent more than 4,000 ISIS fighters in Europe that are loaded on ships and buses full of refugees. However, these observations are potentially misleading. To understand this threat is very important to examine the number of "refugee terrorists" by the total number of refugees, in the total number of terrorists acts. Research done in Western Europe show that the number of refugees terrorists is symbolic in terms of large numbers of refugees arrived in the past two years. Experts on terrorism in the Western states and
\end{abstract}




\section{Seccurity}

Balkans, also warned about hysteric perception that almost every male refugee is a potential terrorist. Concerns about terrorism and refugees are legitimate, but the fear that is expressed normally is increased and worries often are wrong.

Keywords: terrorism, crisis, refugees, Europe, migrations.

\section{Introduction}

The study of terrorism and the study of migration have been two separate fields. While there is a huge literature on both, migration and on terrorism, there are no indepth studies on the intersection of the two phenomena. There are multiple causal relations between (forced/irregular) migration and terrorism but these are generally complex, historically, and the number of criminals and terrorists in mass migration movements has been low but terrorists often have a criminal background to begin with (Schmid, 2016).

Today, there are over 1 billion migrants, about one in seven persons. Each decade, the percentage of migrants as a share of the total population continues to rise, and in the next twenty-five years, the rate of migration is predicted to be higher than during the last twenty-five years. It has become more necessary for people to migrate because of environmental, economic, and political instability (Kareem, 2016) due to process of globalization. Climate change, in particular, may cause international migration to double over the next forty years (Kareem, 2016).

In 2015 the member states of the EU received more than 1,5 million new applications for asylum - nearly half a million of them from Syrians and another half a million from Afghanis, Iraqis, Pakistanis and Nigerians. The names of these countries of origin already suggest a causal link to terrorism. However, there is also a more sinister explanation. Some argue that refugee flows - consisting these days often of mainly young male Muslims - are deliberately used as a kind of "Trojan horse", being part of an "organized invasion" of Muslims into the West. Not just some right-wing xenophobic conspiracy theorists think so, even NATO's supreme commander in Europe, General Philip Breedlove, recently made such a claim, suggesting that refugees are 'weaponised' by Russia against Europe (Schmid, 2016). The director of Europol recently described the current situation as "the highest terrorist threat we have faced for over 10 years." 


\section{Seccurity}

(Mark, 2016). These security concerns are being exacerbated by unprecedented levels of migration into Europe from impoverished and/or war-torn areas of the Middle East, Africa, and the Balkans, with ISIS known to have targeted such routes for infiltration (Robin, 2016). ISIS displayed its ability to strike at the heart of Europe during attacks in Paris in November 2015 and Brussels in January 2016, while those trained by al-Qaeda carried out the January 2015 raid on the Charlie Hebdo (also in Paris). The potency of these groups is enhanced by their ongoing ability to inspire small cells of radicalized supporters living in the West to carry out attacks on their behalf. The vast majority of plots in the West emanate from such supporters, who have claimed a liation with a terrorist group without ever having traveled to popular safe havens such as Iraq, Pakistan, Somalia, Syria, or Yemen, it appears as though Mohamed Lahouaiej Bouhlel, the terrorist who killed 84 people with a 19-ton truck in Nice recently, was one such individual (Robin, 2016).

\section{Analysis of problem}

The conflicts in that past few years generated refugee wave towards EU. EU faced not just with unexpected crisis but with non existing unique policy for solving this huge problem. Refugee crisis for EU become the tip of the iceberg, serious economic pressure, facing with huge social migration and terrorist attacks.

Germany's generosity, and the increasing pragmatism of the Balkan countries, were also contributing factors, the announcement that Germany it would accept any Syrian's asylum application, even if they had previously applied for asylum in other European countries, spurred a bigger wave of arrivals, since people no longer feared being arrested in Hungary, and forced to claim asylum there (Patrick. 2016). Since the beginning of the refugee crisis countries were not well prepared for such a large number of refugees and devoted more to humanitarian issue, but not to the political and security-terrorism. The crisis in these countries found Europe and the Western Balkans not prepared for such a situation, where some countries have sought financial, human and professional assistance to respond according to prescribed legal rules.

Debate about the refugees, both in Europe and the United States, often focuses on the question of terrorism: with the Islamic State raping and beheading with numbing regularity in Iraq and Syria, the fear is that admitting refugees from this part 
of the world will open the door to more terrorism and violence in Europe (Byman, 2015). Conservative voices in Europe have invoked the specter of Europe being flooded with "half a million" Islamic State fighters, while humanitarians dismiss predictions of a terrorism epidemic. Both sides have it wrong. Concerns about terrorism and the refugees are legitimate, but the fears being voiced are usually exaggerated and the concerns raised often the wrong ones (Byman, 2015). Because refugees are from conflict countries (Syria and Iraq) where the ISIS is based and it is normal to be afraid of sending their fighters among refugees who can do many terrorist acts, but this is not their policy. According to Islamic State every good muslim should travel to Islamic State and fight against its enemies and not leaving its state.

Since 2014, Europe has experienced a number of terrorist incidents-including the November 2015 attacks in Paris and the March 2016 bombings in Brussels largely perpetrated in the name of the Islamic State by European fighters returning from the conflicts in Syria and Iraq (Archick. 2016). According to The Religion of Peace from 09/11 till March 2017 in Europe happened 154 terrorist attacks, killed 1106 persons an injured 1324 persons. This cannot be the only concrete evidence to date that terrorist travelers systematically use the flow of refugees to enter Europe unnoticed. Till today we don't have exactly researches about the numbers of terrorist acts and number of persons killed by refugees. Even that it was found that two of the attackers had entered the EU through Greece as part of the large influx of refugees from Syria. However, some incidents have been identified involving terrorists who have made use of migratory flows to enter the EU.

The majority of Europeans believe the influx of refugees across the continent has led to an increase in the likelihood of terrorism. According to a survey by the Pew Research Center, in eight of the ten European countries surveyed at least half are concerned about the terror threat. The majority of people in five nations say refugees will be an economic burden and take away jobs and social benefits. (Independent, 2016). Hungarians, Poles, Greeks, Italians and French identify this as their greatest concern. Sweden and Germany are the only countries where at least half say refugees make their nation stronger because of their work and talents. Fears linking refugees and crime are much less pervasive, although nearly half in Italy and Sweden say refugees are more to blame for crime than other groups. (Pew Research Center, 2016).

While most Europeans think the recent surge of refugees could lead to more terrorism, there is less alarm that Muslims already living on the Continent might 
sympathize with extremists. The percentage of the public saying that most or many Muslims in their country support groups like ISIS is less than half in every nation polled. Still, $46 \%$ of Italians, 37\% of Hungarians, 35\% of Poles and 30\% of Greeks think Muslims in their countries are favorably inclined toward such extremist groups. On these and other questions included on the poll, Greece, Hungary, Italy and Poland often stand out for expressing greater concern and more negative views about refugees and minority groups (Pew Research Center, 2016).

The most frequently quoted arguments are in terms of the following attitudes of the public: refugees are dangerous and pose a threat to national security, refugees pose a threat to the EU economy, refugees have no place in Europe and should seek asylum in the nearest peaceful country in their region instead, refugees are people with another mentality and religion, and a large number of them cannot adopt the European values and model of behavior and cannot possibly integrate in the European community (Kyuchukov, 2016). Refugee crisis is seeing not only humanitarian tragedy but as threat for existence of European Union.

Europe's terrorist threat, while rising, has come overwhelmingly not from foreigners but from fellow Europeans. According to EUROPOL nearly two-thirds of the arrestees for terrorism suspect $432(63 \%)$ in 2016 were EU citizens, the majority were born in the EU (58\%) (Taub, 2016). At the same time, European officials remain concerned about European citizens who have joined other extremist groups, as well as self-radicalized individuals who may not have traveled abroad to fight but who have been motivated by Islamist propaganda to commit violence at home (Archick. 2016). According to the most research organizations the numbers of foreign fighters from Western Europe are more than 5000.

A number of other suspected cases, including terrorist use of fraudulent travelling documents, have since been identified. A real and imminent danger, and one that will probably continue to exist for a long time, is the potential for elements of the (Sunni Muslim) Syrian refugee Diaspora to become vulnerable to radicalization in Europe (EUROPOL, 2016). UN report found little evidence that asylum seekers are inclined to be radicalized, or that terrorist groups systematically use migration flows for their purposes (UN Report, 2016).

Just for comparison the U.S. has accepted more than 3 million refugees since 1975, but few of them attempted terrorist attacks on U.S. soil. But as the Cato report for 2016 called "Terrorism and Immigration" notes, "Refugees were not very successful 


\section{Secururity}

at killing Americans." Only three-all of them from Cuba-managed to mount successful attacks, killing a total of three people. ${ }^{90}$ To put that in context, the percent of Americans arrested for violent crime in 2015 is 250 times greater than the percent of refugees who turn out to be terrorists, successful or otherwise (Irwin, 2017). According to the same report identified 154 foreign-born people, including 20 refugees (these 20 terrorists account for $0.0006 \%$ of all refugees admitted into the country), who were convicted of carrying out or attempting to carry out a terrorist attack in the U.S. over a 40-year period, from 1975 to 2015 (Kiely, 2017). Foreign-born terrorists who entered the country, either as immigrants or tourists, were responsible for $88 \%$ (or 3.024) of the 3.432 murders caused by terrorists on U.S. soil. Only 10 illegal immigrants became terrorists, a minuscule $0.000038 \%$ of the 26.5 million who entered from 1975 through 2015, in other words, 2.65 million illegal immigrants entered the United States for each one who ended up being a terrorist (Nowrasteh, 2016). Including those murdered in the terrorist attacks of September 11, 2001 (9/11), the chance of an American perishing in a terrorist attack on U.S. soil that was committed by a foreigner over the 41-year period studied here is 1 in 3.6 million per year. For instance, the chance of an American being murdered in a terrorist attack caused by a refugee is 1 in 3.64 billion per year while the chance of being murdered in an attack committed by an illegal immigrant is an astronomical 1 in 10.9 billion per year. By contrast, the chance of being murdered by a

${ }^{90}$ According to the CDC, cows caused at least 108 deaths just between 2003-2007. That's about 21 deaths per year, roughly 288 times more than refugees; According to the National Safety Council, injuries sustained from falling down stairs accounted for 1,307 deaths in the year 2000. That's a 1 in 2,739 chance over one's lifetime; According to the Journal of Burn Care and Research, an average of 100 people die each year from burns caused by hot tap water; The CDC found that 279 people died from dog bites between 1979 and 1994, which comes out to an average of about 18 people per year; Roughly 100 people die every year due to bee stings, according to the CDC; An average of eight people die per DAY due to traffic accidents as a result of texting a driving. That's 2,920 people per year; There were 76 wind-related deaths in 2011, and 104 in 2012; NSC statistics show that 357 people died from accidental suffocation or strangulation in bed in the year 2000. So not only is that way, way more than the average of 0.075 deaths per year caused by refugees, but it also means you're actually four times more likely to be suffocated by your own bed than to be killed by a foreign-born terrorist of ANY kind. https://www.buzzfeed.com/andyneuenschwander/13-things-more-likely-to-kill-you-than-arefugee-terrorist?utm_term=.hdJ027R3d\#.ywpKaxyBA Visited on 13, April 2017. 


\section{Seccurity}

tourist on a B visa, the most common tourist visa, is 1 in 3.9 million per year (Nowrasteh, 2016).

Brookings Institute, a center-left think tank in Washington D.C. says that "concerns about terrorism and refugees are legitimate." But they point out that the situations in Europe and the U.S. are very different, for at least three reasons. First, according to the Brookings Institute, European Muslims are more vulnerable to radicalization, partly because of alienation from their communities and governments (The controversy over burkini bans in France is one example of this). While there are exceptions, American Muslims tend to be better integrated into their communities and the surrounding culture. Syrian refugees coming to America face similar challenges, but the U.S. has not had to absorb nearly as many of them as Europe. At the time when Europe has received nearly 700,000 first-time asylum applicants from Syria, the U.S. has resettled fewer than 20,000 over the same period. A second challenge is Europe's proximity to the Middle East. America has not had to deal with collective admission of Syrian refugees in the way that Europe has. Other experts have already noted that the EU is "more exposed to irregular migration flows over its external borders. Third, while questions can (and should) be raised about the strength of America's refugee vetting process, the measures currently in place are among the most rigorous in the world (Irwin, 2017).

Demographic concerns and terrorist acts. Since 1985, Europe received about 11.6 million asylum applications - meaning that last year's 1.3 million amounted to about one-tenth of all applications received during the past 30 years by current EU countries (Pew Research Center, 2016). The European Union's population is about 500 million. According to UNHCR nearly 370,000 refugees and migrants have arrived in Europe in 2016 is $\mathbf{0 . 0 7 4 \%}$ of total Population of Europe. In 2015 more than 1 million refugees and migrants arrived in Europe, many fleeing wars in Asia and the Middle East. Considering the EU's wealth and advanced economy, it is hard to argue that Europe lacks the means to absorb these newcomers. To put this in perspective, the U.S., with a population of 320 million, has some 11 million undocumented immigrants. They make up about $3.5 \%$ of the U.S. population. The EU, by contrast, had between 1.9 and 3.8 million undocumented immigrants in 2008 (the latest available figures), or less than one percent of its population. On 1 January 2016, the number of people living in the EU28 who were citizens of non-member countries was 20.7 million, while the number of people living in the EU-28 who had been born outside of the EU was 35.1 million 


\section{Securiagues}

(Eurostat, 2016). In the USA the percentage of people living in the USA who were born outside the country reached 13,7\% in 2015 (more than 40 million residents) and is projected to hit a record 14,9\% in 2025 according to a Pew Research Center. This is twice the proportion of non-EU foreign-born people living in EU. By comparison, the foreign-born population is $1.63 \%$ of the total population in Japan, $7.7 \%$ in Russia, $20 \%$ in Canada and 27\% in Australia (OECD, 2017).

The biggest concern among the hawkers of crisis seems to be fears about culture. The U.S. has many more undocumented immigrants than the EU and has always been a nation of immigrants, America's vitality is in large part due to the energy and ideas that waves of immigrants have brought to its shores. (Kenneth, 2015). But most European countries do not think of themselves as immigrant nations. Many Europeans fear that an influx of foreigners will undermine their comfortable cultures. Research suggests this concern is a major factor in support for populist extremist parties in many EU countries. That fear is accentuated in largely Christian Europe by the Muslim religion of most of the new arrivals. Some governments Poland, Bulgaria, Slovakia - have expressed a strong preference for only Christian refugees. This disquiet has been building for decades as Europe's population has slowly changed. Predictably, the UKIP party in Britain and politicians such as Marine Le Pen in France, Geert Wilders in the Netherlands, Matteo Salvini of Italy, Milos Zeman in the Czech Republic are now using the refugee surge to accentuate these fears. (Kenneth, 2015).

Implications for counterterrorism. It is clear from the past that mass migration seeking paradise, new opportunities have facilitated the distribution of jihadist terrorism. However, these observations are potentially misleading. To understand this threat will present the report of mass migration and terrorism, and it is necessary to examine the number of "refugee's terrorists" with the total number of refugees. Example of Algerians in the U.K. is illustrative. Prior to the 1990s, relatively few Algerians lived in Britain, but by 2004 the estimated number had risen to between 25,000 and 30,000, according to a study by the Information Centre about Asylum and Refugees in the U.K. By comparison, just 44 Algerians are known, with some degree of certainty, to have been involved in terrorist activity in the U.K. between 1980 and 2013. This works out to less than $0.2 \%$ of the British-Algerian population. The 2010 U.S. Census estimated the country's Somali-born population at about 85,000 , yet only 36 were involved in terrorism up until 2013 , working out to $0.04 \%$. If these examples are 
representative, we can expect far less than $1 \%$ of the current wave of refugees to become involved in terrorism. (Mullins, 2016). It is also apparent that the vast majority of jihad terrorists operating in Western countries did not arrive as refugees. For example, jihad terrorism indicates that $15 \%$ of jihad terrorists who became active in the U.K. prior to 2013 arrived as asylum seekers or refugees. In the U.S., it is just $5 \%$. In these cases, "refugee terrorists" are clearly the minority. Moreover, during the same time, $48 \%$ of British and $61 \%$ of American jihadist came from abroad, as opposed to being born in these countries. These disparities clearly demonstrate that claiming some form of refugee status is not a particularly common method of entry to the West for jihadi terrorists. Indeed, the historical record suggests that terrorists who come from abroad are more likely to enter a given country using a valid visa. (Mullins, 2016). Furthermore, several future jihadi terrorists who did come to the U.K. /U.S. as refugees originally did so as children traveling with their families or were otherwise legitimate claimants at the time they completed the application, only to radicalize later on. They did not, therefore, deliberately infiltrate mass migration flows to conduct acts of terrorism. In many respects they were homegrown terrorists. The Tsarnaev brothers, who had been living in the U.S. for 10 years before they bombed the 2013 Boston Marathon, are a case in point. The average length of time spent living in the West for foreigners who became jihadi terrorists after $9 / 11$ was 9.1 years in the U.K. and 10.7 years in the U.S. Although those who claimed asylum typically became involved in terrorism sooner than this - with respective averages of 1.8 and 5.3 years after entering the country - the fact remains that relatively few jihadi terrorists have entered the West disguised as asylum seekers with the preexisting intention of committing acts of terrorism. Instead, they are far more likely to be radicalized while living in a Western country come to the West from jihadi conflict zones (Mullins, 2016).

\section{Conclusion}

In sum, recent history suggests that although mass migration and terrorism are indeed connected, refugee terrorists are the exception to the rule. (Sam Mullins, 2016). Refugee coming from conflict countries are not primarily a concern for counterterrorism, but this mean that they should not be ignored by law enforcement, and should treat them as according to the law, especially processing and sharing 
information upon their arrival with other agencies and other countries.

The challenge with immigrants is a major problem for all European countries, and this crisis has shown that the EU only works in theory. When faced with this challenge, the EU has not been able to find a common solution. Measures introduced to address the problem are not as effective, every state had an individual approach and the approach is consistent with the national interests and policies, many countries see this situation as a matter of security, while some see as a humanitarian crisis. But the answer is somewhere in the middle. We should not neglect the security aspect of migration issues, but also and the humanitarian dimension. Legal regulation of migration should not be left aside. This movement of people should be done in conformity with these rules. The crisis must be solved by solving the crisis in the countries from which generated all this. We must have a long-term, comprehensive strategy, using various political, diplomatic, economic and security means, while not always bypassing the entire region as countries directly involved in the conflict and other countries around. All this requires commitment not only of state institutions as the main responsible but also and other international organizations such as UNHCR, IOM and other nongovernmental organizations. This applies as usual for states that have little experience with this issue. Terrorists in this context are a drop in the ocean. However, this does not mean that they do not have to go through the standard procedures outlined in the relevant legislation.

\section{References}

1. Byman, D.L. (2015) Do Syrian refugees pose a terrorism threat? October 27, 2015. (Visited 13.04.2017) https://www.brookings.edu/blog/markaz/2015/10/27/dosyrian-refugees-pose-a-terrorism-threat/

2. Archick K. 2016. The European Union: Current Challenges and Future Prospects. Congressional Research Service. https://fas.org/sgp/crs/row/R44249.pdf

3. EUROPOL (2016), European Union Terrorism Situation and Trend Report 2016, https://www.europol.europa.eu/activities-services/main-reports/eu-terrorismsituation-and-trend-report\#fndtn-tabs-0-bottom-2 accesed on 15 April 2017https://en.wikipedia.org/wiki/European_migrant_crisis 


\section{Seccurility}

4. Independent. (2016). Refugee crisis: Majority of Europeans believe increased migration raises terror threat, survey says.

5. Irwin, B. (2017) "4 Things You Should Know About Refugees and Terrorism", February 11, 2017, Visited 13 April 2017, http://www.preemptivelove.org/4_things_about_refugees_and_terrorism

6. Interantional Organization for Migration (IOM), "Migration, Climate Change and the Environment" accesed April 13, 2017, http://www.iom.int/cms/en/sites/iom/home/what-we-do/migration-andclimate-change/a-complex-nexus.html.

7. Kenneth R. (2015). The Refugee Crisis That Isn't. Huffington Post. http://www.huffingtonpost.com/kenneth-roth/the-refugee-crisis-thatisnt_b_8079798.html

8. Kareem M. (2016) DU Philosopher: We're In The Century Of The Migrant, Feb 5, (Visited on 13. April, 2017) http://www.cpr.org/news/story/du-philosopherwere-century-migrant

9. Kiely E. (2017)Refugees and Terrorism Investigations, Posted on March 10, 2017, file://Users/naseretemi/Desktop/punime\%20per\%20publikim/UKIM\%20Nase r/Refugees\%20and\%20Terrorism\%20Investigations\%20\%20FactCheck.org.webarchive accesed 13. April, 2017.

10. Kyuchukov L. (2016). Impact of the Refugee Crisison Bulgarian Society and Politics: Fears But No Hatred. Friedrich-Ebert-Stiftung, Office Bulgaria. Accesed December 2016 http://library.fes.de/pdf-files/bueros/sofia/12570.pdf

11. Kingsley P. (2016). What caused the refugee crisis? The Guardian. Accessed December, 2016.

https://www.theguardian.com/commentisfree/2015/dec/09/what-caused-therefugee-crisis-google

12. Mullins, S. (2016). "Terrorism and mass migration, Terrorists rarely exploit refugee networks to conduct attacks", Per Concordiam, Journal of European Security and Defense Issues. Volume 7. Issue 1.

13. Mark, S. (2016) "Terror Threat to Europe 'Highest for 10 Years," Sky News, March 9, 2016, http://news.sky.com/story/1656134/terror-threat-to-europehighest-for-10-years (accessed April 21, 2016). 
14. Nowrasteh, A. (2016) "Terrorism and Immigration", Policy Analysis, CAT0 Institute, September 13, 2016 | Number 798, Visited on 13, April, 2017https://object.cato.org/sites/cato.org/files/pubs/pdf/pa798_2.pdf

15. Pew Research Center (August, 2016) "Number of Refugees to Europe Surges to Record 1.3 Million in 2015" Visited on 14, April 2017. http://assets.pewresearch.org/wpcontent/uploads/sites/2/2016/08/PGM_2016.08.02_Europe-Asylum_Final.pdf

16. Robin, S. (2016) The Threat of Islamist Terrorism in Europe and How the U.S. Should Respond, The Heritage Foundation, No. 3142, August 1, 2016. http://www.heritage.org/terrorism/report/the-threat-islamist-terrorismeurope-and-how-the-us-should-respond\#_ftn2 (accessed April 13, 2017)

17. Report of the Special Rapporteur on the promotion and protection of human rights and fundamental freedoms while countering terrorism, United Nations, General Assembly,

18. Distr.: General 13 September 2016, https://documents-dds ny.un.org/doc/UNDOC/GEN/N16/285/61/PDF/N1628561.pdf?OpenElement Accesed on 14 April 2017

19. Schmid, A.P. (2016) "Links between Terrorism and Migration: An Exploration" The International Centre for Counter-Terrorism - The Hague 7, no. 4 Visited on 13, April, 2017, https://www.icct.nl/wpcontent/uploads/2016/05/Alex-P.-Schmid-Links-between-Terrorism-andMigration-1.pdf

20. Taub, T. (2016), Shutting down immigration won't solve Europe's terrorism problem, posted on March 22, 2016,

21. http://www.vox.com/2016/3/22/11285962/brussels-attack-refugeesimmigration (Visited on 11, April, 2017). 